\title{
THE USE OF SODIUM p-AMINOHIPPURATE FOR THE FUNCTIONAL EVALUATION OF THE HUMAN KIDNEY ${ }^{1}$
}

\author{
BY HERBERT CHASIS, JULES REDISH, WILLIAM GOLDRING, \\ HILMERT A. RANGES, AND HOMER W. SMITH

\begin{abstract}
(From The Departments of Physiology and Medicine, New York University College of Medicine,
\end{abstract} \\ and the Third (New York University) Division of Bellevue Hospital, New York City)
}

(Received for publication January 16, 1945)

The advantages of $\mathrm{p}$-aminohippuric acid over diodrast for the measurement of the effective renal plasma flow and tubular excretory mass have been noted in a previous paper (1). The present report describes the determination of tubular excretory capacity by p-aminohippuric acid $\left(T m_{P A H}\right),{ }^{2}$ the quantitative relations between filtration rate, effective renal plasma flow, and $T m_{P A B}$ in 31 normal subjects, in 10 patients with essential hypertension and in 3 patients with glomerulonephritis, and presents a comparison of $T m_{P A B}$ with the equivalent diodrast measurement $\left(T m_{D}\right)$ in a number of these individuals.

The subjects were volunteers from the Third (New York University) Medical Division of Bellevue Hospital. Those considered normal were afebrile.

\section{METHODS}

The data were collected by two methods. The first, designated here as the multiple period method and identical with the method used in previous studies from this laboratory $(2,3)$, consists of the determination of $T m_{D}$ or $T_{m_{P A B}}$ by 5 or more successive urine collection periods of about 10 minutes each. The following stock solutions are used in the preparation of the infusion fluid: inulin 10 per cent, mannitol 25 per cent, diodrast 35 per cent, sodium p-aminohippurate 20 per cent. For the measurement of effective renal plasma flow and glomerular filtration rate, a priming infusion of $80 \mathrm{ml}$. of mannitol or $30 \mathrm{ml}$. of inulin and $2.3 \mathrm{ml}$. of diodrast or $4 \mathrm{ml}$. of sodium $\mathrm{p}$-aminohippurate is mixed in a sterile 250 $\mathrm{ml}$. flask and administered intravenously at the rate of $20 \mathrm{ml}$. per minute. This is immediately followed by a

1 Aided by a grant from the Commonwealth Fund.

2 A sterile solution (20 per cent) of sodium p-aminohippurate in $50 \mathrm{ml}$. ampoules and Reagent grade p-aminohippuric acid were supplied through the courtesy of the Medical-Research Division of Sharp and Dohme, Philadelphia, $\mathrm{Pa}$. We are indebted to Sharp and Dohme for making available substantial quantities of these materials for clinical as well as experimental trial. sustaining infusion consisting of $80 \mathrm{ml}$. of mannitol, 70 $\mathrm{ml}$. of inulin, and $10 \mathrm{ml}$. of diodrast or $20 \mathrm{ml}$. of sodium p-aminohippurate, made up to a total volume of $500 \mathrm{ml}$. with normal saline and administered intravenously at the rate of $4 \mathrm{ml}$. per minute.

For the measurement of maximal tubular excretory capacity $\left(T m_{D}\right.$ or $\left.T m_{P A B}\right)$, the infusion is stopped and a priming injection is made into the infusion tubing of 30 $\mathrm{ml}$. of diodrast or $60 \mathrm{ml}$. of sodium p-aminohippurate, administered over a period of 10 minutes. The residual infusion is reinforced by the addition of $0.18 \mathrm{ml}$. of diodrast or $0.43 \mathrm{ml}$. of sodium p-aminohippurate per $\mathrm{ml}$. of infusion remaining in the flask, after which the infusion rate is restored to $4 \mathrm{ml}$. per minute. The methods of collecting blood and urine samples are described in the above references.

The second or single period method, described below, represents part of a composite renal function test recently introduced for general clinical use (4). This test is designed to measure maximal concentration power, effective renal plasma flow, filtration rate, and maximal tubular excretory capacity with a minimal number of technical procedures. No breakfast is given on the morning of the test. Between 9:00 and 9:30 a.m., the patient drinks 1 liter of water. At the end of this time, a venous blood sample $\left(B_{0}\right)$ is taken for plasma blanks and hemocrit, and a priming infusion of $30 \mathrm{ml}$. of inulin or $80 \mathrm{ml}$. of mannitol and $3 \mathrm{ml}$. of sodium p-aminohippurate is administered intravenously from an infusion flask, over a period of about 2 minutes. The sustaining infusion, consisting of $42 \mathrm{ml}$. of inulin or $66 \mathrm{ml}$. of mannitol and $10 \mathrm{ml}$. of sodium p-aminohippurate, made up to $350 \mathrm{ml}$. with normal saline, is added to the infusion flask as soon as the priming infusion has reached the neck and is administered at the rate of $4 \mathrm{ml}$. per minute. Following a 20 -minute discard period, the bladder is emptied by catheter and rinsed one or more times with about $20 \mathrm{ml}$. of saline, and a blood sample $\left(B_{1}\right)$ is taken. Twenty minutes later the bladder is emptied and rinsed again, and a second blood sample $\left(B_{2}\right)$ is drawn.

For $T m_{P A B}$ measurement, a priming dose of $60 \mathrm{ml}$. of 20 per cent sodium p-aminohippurate ${ }^{3}$ is injected into the

\footnotetext{
${ }^{3}$ In earlier tests, $200 \mathrm{ml}$. of 10 per cent sodium p-aminohippurate were infused over a period of about 30 minutes as a priming dose, but it was found that the smaller quantity was adequate and could be given in a shorter time.
} 
TABLE I

Subjects with normal renal function. Multiple period method

In this and subsequent tables, all clearance and Tm values are corrected to $1.73 \mathrm{sq} . \mathrm{m}$. body surface area.

\begin{tabular}{|c|c|c|c|c|c|c|c|c|c|c|c|c|}
\hline Subject & Sex & Date & $\begin{array}{c}\text { Plasma } \\
\text { clearance } \\
\text { (Man- } \\
\text { nitol) }\end{array}$ & \multicolumn{2}{|c|}{${ }^{T m_{D}}$} & \multicolumn{2}{|c|}{${ }^{T} m_{P A H}$} & \multicolumn{2}{|c|}{$T m_{P A H^{\prime}} / T m_{D}$} & \multirow{3}{*}{$\begin{array}{c}\frac{C_{M}}{T m_{D}} \\
3.07\end{array}$} & \multirow{3}{*}{$\begin{array}{c}\frac{C_{M}}{T m_{P A H}} \\
1.69\end{array}$} & \multirow[t]{2}{*}{ Diagnosis } \\
\hline \multirow{4}{*}{$\begin{array}{l}\text { A. A. } \\
\text { L. B. } \\
\text { A. P. }\end{array}$} & \multirow{2}{*}{ F } & \multirow{14}{*}{$\begin{array}{r}4-20-42 \\
4-24-42 \\
5-1-42 \\
5-8-42 \\
5-15-42 \\
5-20-42 \\
5-18-42 \\
6-11-42 \\
5-22-42 \\
5-29-42 \\
5-25-42 \\
5-27-42 \\
10-28-42 \\
11-2-42 \\
11-11-42 \\
11-13-42 \\
6-2-43 \\
6-4-43 \\
6-7-43 \\
6-11-43\end{array}$} & $\begin{array}{l}\text { ml. per } \\
\text { minute }\end{array}$ & $\begin{array}{c}\text { mgm. } \\
\text { iodine } \\
\text { per } \\
\text { minute }\end{array}$ & $\begin{array}{c}\text { mM per } \\
\text { minute }\end{array}$ & $\begin{array}{c}\text { mgm. per } \\
\text { minute }\end{array}$ & $\begin{array}{c}m M \text { per } \\
\text { minute }\end{array}$ & $\begin{array}{l}m g m \\
P A H \\
m g m . \\
\text { modine } \\
\text { iodine }\end{array}$ & $\begin{array}{c}m M \\
P A H \\
P M \\
\text { iodine }\end{array}$ & & & \\
\hline & & & \multirow{13}{*}{\begin{tabular}{|c}
115 \\
122 \\
132 \\
122 \\
79.0 \\
72.9 \\
119 \\
111 \\
81.6 \\
66.3 \\
110 \\
97.3 \\
83.6 \\
106 \\
91.8 \\
68.1 \\
99.0 \\
108 \\
81.1 \\
87.4
\end{tabular}} & \multirow{2}{*}{39.8} & \multirow{2}{*}{0.157} & 69.2 & 0.357 & 1.74 & 2.27 & & & \multirow{4}{*}{$\begin{array}{l}\text { Peptic ulcer } \\
\text { Sciatica } \\
\text { Chronic chole- } \\
\text { cystitis } \\
\text { Sciatica }\end{array}$} \\
\hline & $\mathbf{M}$ & & & & & 68.6 & 0.354 & & \multirow[b]{2}{*}{1.73} & \multirow[b]{2}{*}{2.34} & 1.93 & \\
\hline & $\mathrm{F}$ & & & 52.1 & 0.205 & 51.5 & 0.365 & 1.32 & & & 1.53 & \\
\hline H. Mc. & $F$ & & & 37.3 & 0.147 & 879 & 0.453 & 1.38 & 2.48 & 1.95 & 135 & \\
\hline & & & & 51.5 & 0.203 & & & 1.71 & 2.23 & \multirow{2}{*}{$\begin{array}{l}2.16 \\
1.89\end{array}$} & & \multirow{4}{*}{$\begin{array}{l}\text { Upper respiratory } \\
\text { infection } \\
\text { Streptococcal } \\
\text { pharyngitis } \\
\text { Cholecystitis }\end{array}$} \\
\hline C. & M & & & 35.3 & 0.139 & 64.4 & 0.332 & \multirow{2}{*}{1.82} & \multirow{2}{*}{2.39} & & 1.27 & \\
\hline . H. & $\mathbf{M}$ & & & 412 & & 78.5 & 0.405 & & & \multirow{3}{*}{$\begin{array}{l}2.36 \\
2.06\end{array}$} & 1.39 & \\
\hline \multirow{3}{*}{$\begin{array}{l}\text { B. M. } \\
\text { E. T. }\end{array}$} & $\mathbf{M}$ & & & 40.6 & 0.160 & & & 1.90 & 2.50 & & & \\
\hline & & & & & & 63.4 & 0.327 & 1.56 & 2.04 & & 1.67 & $\log _{1}$ \\
\hline & $\mathbf{M} 1$ & & & 31.0 & 0.1 & 61 & & 15 & $261+2+2$ & \multirow{2}{*}{2.19} & & \multirow{4}{*}{$\begin{array}{l}\text { Rheumatoid } \\
\text { arthritis } \\
\text { Sacro-iliac strain }\end{array}$} \\
\hline & $F$ & & & 39.0 & 0.154 & & & & & & & \\
\hline \multirow{2}{*}{ W. D. } & & & & & & 73.7 & 0.380 & 1.89 & 2.47 & \multirow{2}{*}{2.81} & 1.47 & \\
\hline & 101 & & & 28.8 & 0.113 & 57.2 & 0.295 & 1.99 & 2.61 & & 1.53 & \\
\hline & $\begin{array}{l}m \\
\sigma \\
\sigma / m\end{array}$ & & $\begin{array}{l}97.6 \\
17.8 \\
18.2\end{array}$ & $\begin{array}{c}39.7 \\
7.18 \\
18.1\end{array}$ & & $\begin{array}{l}67.6 \\
10.0 \\
14.8\end{array}$ & & $\begin{array}{c}1.73 \\
0.24 \\
13.9\end{array}$ & $\begin{array}{c}2.33 \\
0.29 \\
12.4\end{array}$ & $\begin{array}{r}2.33 \\
0.32 \\
13.7\end{array}$ & $\begin{array}{c}1.53 \\
0.21 \\
13.7\end{array}$ & \\
\hline
\end{tabular}

infusion tubing, with the infusion stopped, the injection requiring about 10 minutes, and then $0.43 \mathrm{ml}$. of sodium p-aminohippurate are added to each $\mathrm{ml}$. of the residual infusion, after which the rate of infusion is restored to $4 \mathrm{ml}$. per minute.

Twenty minutes from the end of the priming injection, the bladder is emptied and rinsed and a blood sample $\left(B_{\mathbf{z}}\right)$ is taken. Twenty minutes later, another blood sample $\left(B_{4}\right)$ is taken and the second urine specimen $\left(U_{2}\right)$ collected by rinsing. The concentrations of the essential substrates as determined in the separated plasma from the 4 blood samples are plotted on semilogarithmic paper against time and the mean plasma concentrations determined by interpolation to the middle of the 2 urine collection periods. These values, with the analytical data derived from the 2 urine samples, are used to calculate the effective renal plasma flow, filtration rate, and $T m_{P A B}$.

$\left(T m_{D}\right.$ measurements were not made by the single period method in this paper, but this procedure will fit into the single period method, the doses required being the same as those described above for the multiple period method.)

The above quantities of diodrast and sodium p-aminohippurate in the sustaining infusion are recommended for patients with normal or moderately depressed renal function, and must be proportionately reduced in patients with marked functional impairment. This is essential in the determination of effective renal plasma flow, since elevation of the plasma level of diodrast iodine or p-aminohippuric acid above 3 and $4 \mathrm{mgm}$. per cent, respectively, may depress the renal extraction ratio.

Plasma is precipitated by cadium sulfate and p-aminohippuric acid is determined as described elsewhere (1). Inulin is determined by a modification (4) of Harrison's method (5), diodrast by Alpert's method (6) and mannitol by the method of Smith, Finkelstein, and Smith (7). The p-aminohippuric acid plasma blank is determined additively, i.e., by the addition of a known amount of substrate to the $B_{0}$ filtrate (1). Inulin and mannitol plasma blanks are determined by adding known quantities of substrate to a sample of $B_{0}$ plasma, prior to treatment with yeast and precipitation. ${ }^{4}$ Equivalent aqueous dilu-

4 Re-examination of the inulin method, now in process, reveals that apparently fructose-free inulin (repeatedly recrystallized) is taken up to an appreciable extent by yeast and recoveries are therefore less than 100 per cent. This deficient recovery tends to be compensated by an inulinoid blank derived from the yeast itself.

Loss of inulin onto yeast is not a significant source of error if plasmas and urines are yeasted and precipitated in an identical manner. The appropriate blank to be deducted from the plasma may be determined additively in the $B_{0}$ filtrate, i.e., by diluting a small quantity of stand- 
TABLE $\mathbf{n}$

Subjects with normal renal function. Single period method

\begin{tabular}{|c|c|c|c|c|c|c|c|c|c|}
\hline \multirow{2}{*}{ Subject } & \multirow{2}{*}{ Sex } & \multirow{2}{*}{ Date } & \multicolumn{2}{|c|}{ Plasma clearance } & \multirow{2}{*}{$T m P A H$} & \multirow{2}{*}{$\frac{C_{I N}}{C_{P A B}}$} & \multirow{2}{*}{$\frac{C_{I N}}{T m_{P A H}}$} & \multirow{2}{*}{$\frac{C_{P A H}}{T m_{P A H}}$} & \multirow[b]{2}{*}{ Diagnosis } \\
\hline & & & $\underset{C_{I N}}{\text { (Inulin) }}$ & $\begin{array}{l}(P A B) \\
C_{P A H}\end{array}$ & & & & & \\
\hline $\begin{array}{l}\text { J. M. } \\
\text { C. Mc. } \\
\text { D. D. } \\
\text { S. L. } \\
\text { R. P. } \\
\text { M. R. } \\
\text { J. Y. } \\
\text { A. F. } \\
\text { C. O. } \\
\text { L. P. } \\
\text { G. L. } \\
\text { C. S. } \\
\text { J. H. } \\
\text { P. S. } \\
\text { A. L. } \\
\text { P. M. } \\
\text { P. E. } \\
\text { M. G. } \\
\text { J. O. } \\
\text { A. K. } \\
\text { R. C. } \\
\text { J. W. }\end{array}$ & $\begin{array}{l}\mathbf{M} \\
\mathbf{M} \\
\mathbf{F} \\
\mathbf{M} \\
\mathbf{F} \\
\mathbf{F} \\
\mathbf{M} \\
\mathbf{M} \\
\mathbf{M} \\
\mathbf{F} \\
\mathbf{M} \\
\mathbf{M} \\
\mathbf{M} \\
\mathbf{F} \\
\mathbf{F} \\
\mathbf{M} \\
\mathbf{F} \\
\mathbf{M} \\
\mathbf{M} \\
\mathbf{F} \\
\mathbf{M} \\
\mathbf{M}\end{array}$ & $\begin{array}{r}4-6-43 \\
4-9-43 \\
4-14-43 \\
4-21-43 \\
5-6-43 \\
5-10-43 \\
5-11-43 \\
5-18-43 \\
5-19-43 \\
5-25-43 \\
5-26-43 \\
11-3-43 \\
11-10-43 \\
11-15-43 \\
11-26-43 \\
12-3-43 \\
12-10-43 \\
12-27-43 \\
12-29-43 \\
1-13-44 \\
1-24-44 \\
4-24-44 \\
4-27-44\end{array}$ & $\begin{array}{c}\text { ml. per } \\
\text { minute } \\
135 \\
88.5 \\
106 \\
90.8 \\
115 \\
97.8 \\
130 \\
153 \\
123 \\
101 \\
103 \\
136 \\
103 \\
99.7 \\
107 \\
114 \\
94.2 \\
99.8 \\
98.7 \\
96.8 \\
139 \\
143 \\
141\end{array}$ & $\begin{array}{l}494 \\
543 \\
606 \\
748 \\
769 \\
954 \\
536 \\
\\
708 \\
506 \\
675 \\
464 \\
696 \\
445 \\
508 \\
765 \\
529 \\
539 \\
681 \\
709\end{array}$ & $\begin{array}{c}\underset{\text { minute }}{\operatorname{mgm}} \mathbf{p e r} \\
96.4 \\
104 \\
66.4 \\
87.4 \\
84.3 \\
68.6 \\
94.9 \\
74.8 \\
75.8 \\
85.4 \\
82.2 \\
78.6 \\
96.4 \\
76.8 \\
79.8 \\
77.2 \\
\mathbf{6 2 . 0} \\
90.7 \\
\mathbf{6 2 . 1} \\
93.7 \\
\mathbf{8 8 . 3}\end{array}$ & $\begin{array}{l}0.184 \\
0.213 \\
0.162 \\
0.174 \\
0.199 \\
0.130 \\
0.188 \\
\\
0.192 \\
0.203 \\
0.148 \\
0.229 \\
0.164 \\
0.212 \\
0.196 \\
0.130 \\
0.183 \\
0.257 \\
0.211 \\
0.199\end{array}$ & $\begin{array}{l}1.40 \\
0.854 \\
1.59 \\
1.04 \\
1.36 \\
1.42 \\
1.37 \\
2.04 \\
1.63 \\
1.18 \\
1.25 \\
1.73 \\
1.07 \\
1.30 \\
1.34 \\
1.48 \\
1.52 \\
1.09 \\
1.56 \\
1.48 \\
1.59\end{array}$ & $\begin{array}{c}5.64 \\
6.44 \\
6.83 \\
7.88 \\
10.3 \\
12.6 \\
6.27 \\
\\
9.00 \\
5.25 \\
8.79 \\
5.82 \\
9.02 \\
7.17 \\
8.44 \\
8.51 \\
5.75 \\
8.03\end{array}$ & $\begin{array}{l}\text { Upper respiratory infection } \\
\text { Upper respiratory infection } \\
\text { Pneumococcal pneumonia } \\
\text { Chronic bronchitis } \\
\text { Pneumococcal pneumonia } \\
\text { Rheumatoid arthritis } \\
\text { Upper respiratory infection } \\
\text { Rheumatic fever } \\
\text { Upper respiratory infection } \\
\text { Cholelithiasis } \\
\text { Pneumococcal pneumonia } \\
\text { Filariasis } \\
\text { Duodenal ulcer } \\
\text { Chronic alcoholism } \\
\text { Primary atypical pneumonia } \\
\text { Upper respiratory infection } \\
\text { Hysteria } \\
\text { Pneumococcal pneumonia } \\
\text { Pneumococcal pneumonia } \\
\text { Pneumococcal pneumonia } \\
\text { B. Friedlander pneumonia } \\
\text { Upper respiratory pneumonia }\end{array}$ \\
\hline & & $\begin{array}{l}m \\
\sigma \\
\sigma / m\end{array}$ & $\begin{array}{l}112 \\
15.5 \\
13.8\end{array}$ & $\begin{array}{r}621 \\
133 \\
21.4\end{array}$ & $\begin{array}{l}82.2^{*} \\
11.1 \\
13.5\end{array}$ & $\begin{array}{l}0.187 \\
0.03 \\
16.0\end{array}$ & $\begin{array}{c}1.41 \\
0.27 \\
19.1\end{array}$ & $\begin{array}{l}7.74 \\
1.86 \\
24.1\end{array}$ & \\
\hline
\end{tabular}

* The mean value of $T m_{P A B}$ obtained by combining the observations in 31 subjects using the single (Table I) and multiple (Table II) period technic was $77.5 \pm 12.9$.

tions of inulin or mannitol should be yeasted and precipitated and the resulting values deducted from the total $B_{0}$ recovery to obtain the appropriate $B_{0}$ correction. Urine samples diluted to a $U / P$ ratio of approximately 1.0 are yeasted and precipitated in the same manner as plasmas.

The equation used for the calculation of $T m$ is that of Smith, Goldring, and Chasis (8),

$$
T_{m}=U V-P C_{I I} F W=\left[\left(C_{D} / C_{I I}\right)-F W\right] P C_{I I}
$$

where $U$ and $P$ are the concentrations of diodrast iodine (or p-aminohippuric acid) in mgm. per $\mathrm{ml}$. of urine and plasma, respectively, $V$ is the urine flow in ml. per minute, $C_{I I}$ is the inulin (or mannitol) clearance, and $C_{D}$ is the diodrast (or p-aminohippurate) clearance in ml. of plasma per minute. $F W$ is taken as 0.73 for diodrast (8) and as 0.83 for p-aminohippuric acid (1).

During the administration of the priming dose of sodium p-aminohippurate, nearly all patients complained of a sensation of warmth which began in the lumbar region, the epigastrium, or the perineum and, at times, was felt over the entire body. The sensation persisted until 3 to 5 minutes after the injection had been completed. Despite

ard inulin solution with the $B_{0}$ filtrate prepared without the addition of inulin. The same procedure is applicable to mannitol. an intense subjective sensation of warmth, the rectal temperature remained normal and no change in skin color was visible, although in some individuals perspiration was noted. The pulse rate and blood pressure remained unchanged. The only other reactions were occasional headache or nausea which disappeared after cessation of the priming dose. Three out of 43 patients vomited and 2 had a formed bowel movement about 5 minutes after the end of the injection. In most instances, symptoms could be controlled or prevented by slowing the rate of injection and in no case was it necessary to discontinue administration of the drug.

\section{RESULTS}

Four sets of data are presented in the tables: a comparison of $T m_{D}$ and $T m_{P A B}$ in 10 normal subjects (i.e., convalescent patients who were free of immediate evidences or history of renal disease), these values being determined on separate occasions and each datum representing the mean of 5 or more successive urine collection periods (Table I); an extension of observations on $T m_{P A B}$ in 22 normal subjects by the single period 
TABLE III

Subjects with essential hypertension. Single period method

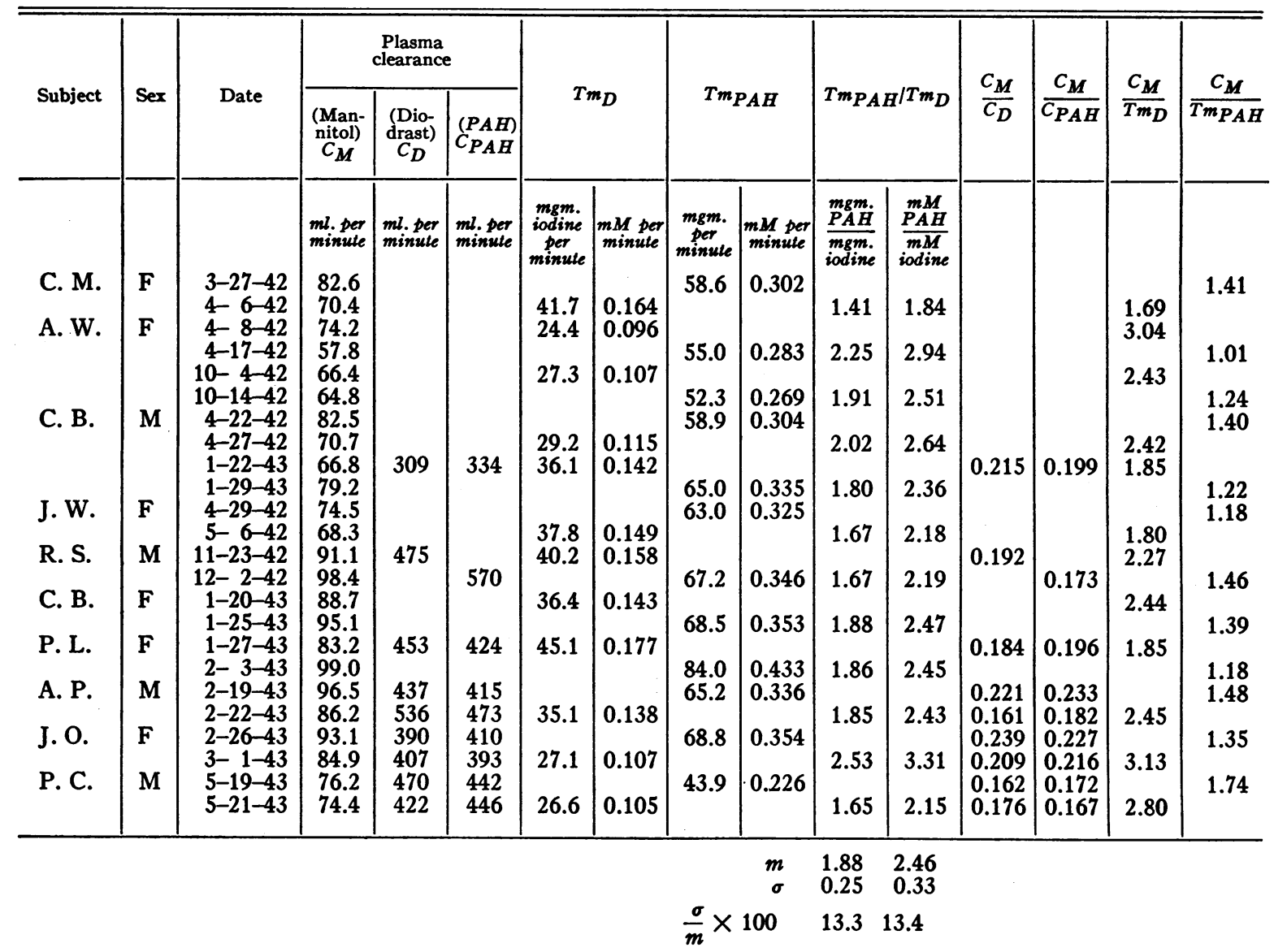

method (Table II); a comparison of $T m_{D}$ and $T m_{P A B}$ in 10 subjects with essential hypertension (Table III); and a similar comparison in 3 subjects with glomerulonephritis (Table IV).

The data obtained by the multiple (Table I) and single period (Table II) methods have been summarized separately and treated statistically.

The mean value of $T m_{P A H}$ obtained by the multiple period method (67.6) is lower than that obtained by the single period method (82.2). However, the first group is only half as large as the second, and the mean value of $T m_{D}$ in the first group $(39.7 \pm 7.2)$ is lower than that previously obtained for either males $(51.8 \pm 8.73)$ or females $(42.6 \pm 9.46)(3)$. This discrepancy appears to be attributable to chance distribution, since the ratio of $C_{\mathrm{r}} / T m_{\mathrm{D}}$ in this group (2.33) approaches the values previously reported for normal subjects ( 2.63 for men and 2.81 for women)
(3) and since the $C_{M}$ (or $\left.C_{I N}\right) / T m_{P A H}$ ratios in the 2 groups in the present study are nearly identical (1.53 and 1.41). We therefore infer that the difference in $T m_{P A H}$ in the multiple period (Table I) and single period (Table II) groups is not related to the differences in the methods of study, and we feel justified in combining the 2 groups in arriving at a mean, normal value of $T m_{P A H}$. This value, as cited in Table II, is $77.5 \pm 12.9$. Since the total number of subjects is too small to permit subdivision by sexes, the establishment of a mean value for each sex must await the collection of more data.

The ratio $T m_{P A H} / T m_{D}$, when calculated on a molar basis, averages $(2.33 \pm 0.32)$, a figure considerably higher than in the dog, in which species it has a value of approximately 1.0 (1). This species difference has no explanation at the present time. In the limited number of patients stud- 
TABLE IV

Subjects with glomerulonephritis. Multiple period method

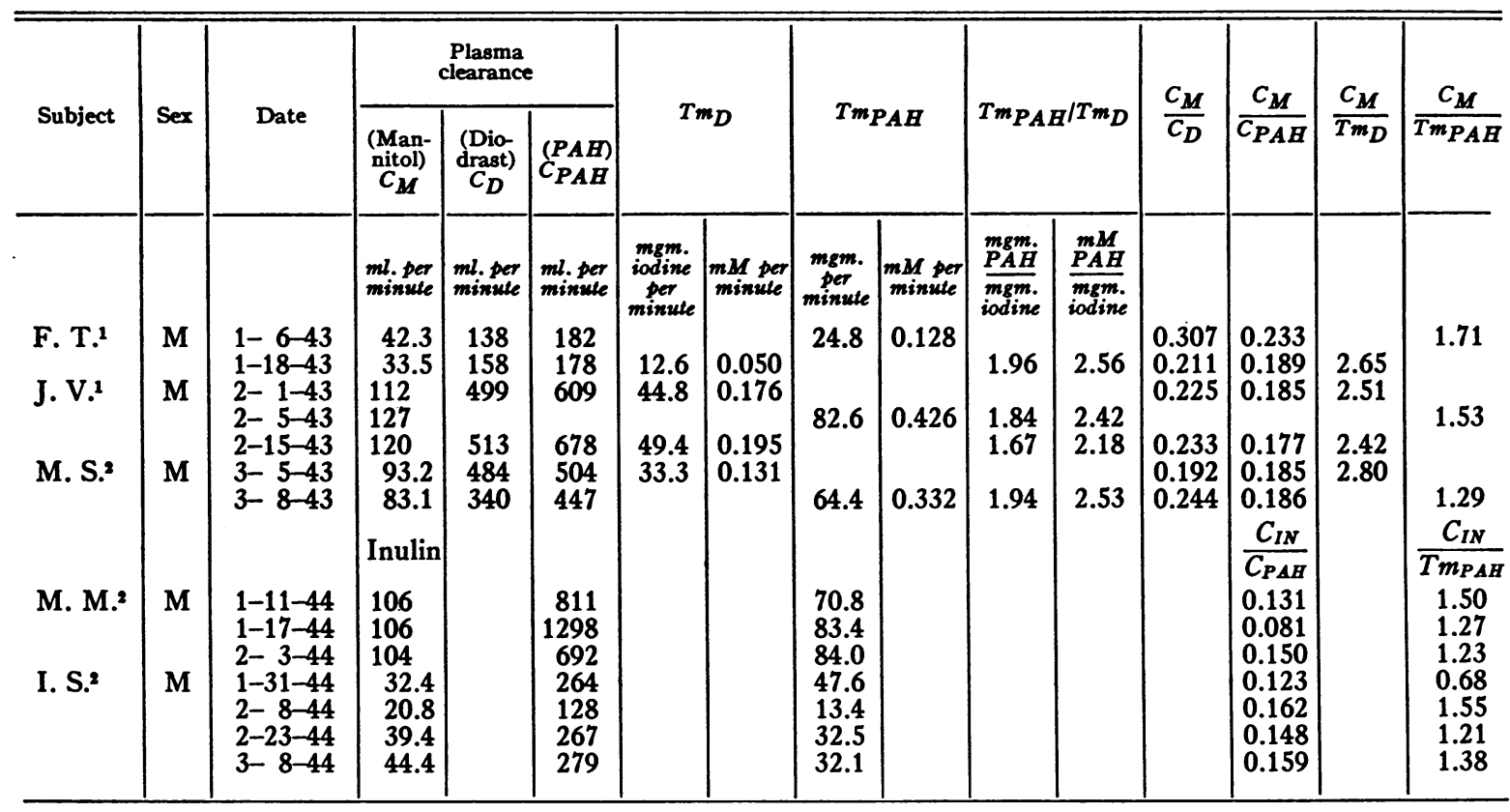

1 Chronic diffuse glomerulonephritis.

2 Acute diffuse glomerulonephritis.

ied here, this ratio remains unchanged in the presence of essential hypertension and glomerulonephritis, indicating that in these subjects the loss of capacity on the part of the renal tubules to excrete diodrast is accompanied by a parallel loss of capacity to excrete p-aminohippuric acid. Whether or not this relationship will hold at all stages and in all forms of renal disease remains to be determined.

\section{SUM MARY}

Procedures are presented for the determination of the effective renal plasma flow $\left(C_{P A H}\right)$ and the maximal rate of tubular excretion $\left(T m_{P A B}\right)$ of p-aminohippuric acid.

The mean value of $T m_{P A B}$ in a group of 31 normal subjects is $77.5 \pm 12.9 \mathrm{mgm}$. per minute per 1.73 square meters of body surface. Values are also given for $T m_{P A B}$ in patients with essential hypertension and in 3 patients with glomerulonephritis.

The molar ratio of the maximal rate of tubular excretion of p-aminohippuric acid to that of diodrast $\left(T m_{P A H} / T m_{D}\right)$ is $2.35 \pm 0.32$ in 10 normal subjects. Practically the same ratio $(2.46 \pm 0.33)$ is found in 10 subjects with essential hyperten- sion. In 1 patient with acute and 2 with chronic diffuse glomerulonephritis, the ratio appears to be similar.

The intravenous administration of relatively large doses of sterile solutions of sodium p-aminohippurate causes no disturbing symptoms if the rate of injection is approximately $6 \mathrm{ml}$. of a 20 per cent solution per minute.

We are indebted to Miss Norma Finkelstein, Miss Martha Barrett, Miss Claire Lawler, Miss Betty Crawford and Mrs. Ilsa Langer for the inulin and mannitol determinations, and to Nurse Grace Volpé for clinical assistance.

\section{BIBLIOGRAPHY}

1. Smith, H. W., Finkelstein, N., Aliminosa, L., Crawford, B., and Graber, M., The renal clearances of substituted hippuric acid derivatives and other aromatic acids in dog and man. J. Clin. Invest., 1945, 24, 388.

2. Goldring, W., Chasis, H., Ranges, H. A., and Smith, H. W., Relations of effective renal blood flow and glomerular filtration to tubular excretory mass in normal man. J. Clin. Invest., 1940, 19, 739.

3. Smith, H. W., Lectures on the Kidney. University Extension Division, University of Kansas, Lawrence, Kansas, 1943. Application of saturation methods to the study of glomerular and tubular 
function in the human kidney. J. Mt. Sinai Hosp., 1943, 10, 59.

4. Goldring, W., and Chasis, H., Hypertension and $\mathrm{Hy}$ pertensive Disease. The Commonwealth Fund, New York, 1944.

5. Harrison, H. E., A modification of the diphenylamine method for determination of inulin. Proc. Soc. Exper. Biol. and Med., 1942, 49, 111.

6. Alpert, L. K., A rapid method for the determination of diodrast-iodine in blood and urine. Bull. Johns Hopkins Hosp., 1941, 68, 522.
7. Smith, W. W., Finkelstein, N., and Smith, H. W., Renal excretion of hexitols (sorbitol, mannitol, and dulcitol) and their derivatives (sorbitan, isomannide, and sorbide) and of endogenous creatininelike chromogen in dog and man. J. Biol. Chem., $1940,135,231$.

8. Smith, H. W., Goldring, W., and Chasis, H., The measurement of tubular excretory mass, effective blood flow and filtration rate in the normal human kidney. J. Clin. Invest., 1938, 17, 263. 